\title{
TRANSPIRED SOLAR COLLECTORS IN BUILDING SERVICE ENGINEERING: COMBINED SYSTEM OPERATION AND SPECIAL APPLICATIONS
}

\author{
B. BOKOR ${ }^{\mathrm{a}}$, L. KAJTÁR \\ Department of Building Service and Process Engineering, Budapest University of Technology and Economics, \\ H-1111 Budapest, Müegyetem rakpart 3-9, Hungary \\ aE-mail: bokor@epget.bme.hu \\ bE-mail:kajtar@epget.bme.hu
}

One of the easiest ways to integrate renewable sources of energy into the heat producing system of a building is the application of transpired solar collectors. They are widespread in North America, where air heating is a common heating alternative, but they are gaining bigger share in the European solar thermal market nowadays. Their simple construction, maintenance-free operation and high working efficiency result in low capital and operating costs. The combination of TSC with other system elements results in additional benefits. Preheating the combustion air of large-scale boilers results in the increase of boiler efficiency and thus the reduction of natural gas consumption and $\mathrm{CO}_{2}$ emission. Whether to choose TSC or heat recovery unit for a certain air conditioning system has to be investigated by examining efficiency-influencing factors of both systems. Besides solar air heating, transpired solar air collectors can reduce the cooling demand on a building. Roof ventilation and nocturnal radiant cooling are two alternatives, which are being presented in the current paper.

\section{Introduction}

Transpired solar collectors use solar energy for heating up fresh air which can be used for building heating, ventilation processes, drying technologies or even combustion air preheating. Canadian engineer John Hollick invented the TSC [1], which has been a subject of research since the early 1990s. Several articles reported on the energy analysis, optimisation of the TSC, while some researchers investigated its operation together with other building service engineering system elements. Eryener and Akhan [2] investigated the opportunity of integrating a capillary radiant heating system onto the back plate of the transpired solar collector, to supplement heating energy for conditions with low solar radiation. Later Eryener and Akhan [3] reported about the combination of a TSC with a waste heat utilization system on the production hall of an automotive company in Turkey. Ameri et al. [4] designed, constructed and tested a TSC combined with PV panels in Iran. Results show that it is possible to cool a PV panel by generating airflow through the perforated plate.

As literature shows, it is possible to combine the TSC with various systems in building service engineering in order to maximize their benefits by the combined operation. The aim of the current article is to introduce problems and tasks authors investigate during the research of TSC supported boilers and air conditioning systems.

\section{TSC construction and operational principle}

Solar air heating is an effective way of providing a building with renewable energy, at low capital costs.

This is an open-access article distributed under the terms of the Creative Commons Attribution-NonCommercial 4.0 International License (https://creativecommons.org/licenses/by-nc/4.0/), which permits unrestricted use, distribution, and reproduction in any medium for non-commercial purposes, provided the original author and source are credited, a link to the CC License is provided, and changes - if any - are indicated. 
Transpired solar collectors, which are common in North America and are getting more and more widespread in Europe, too, represent a remarkable segment of the solar air heating market. Their construction, operational principle and the benefits of application are detailed below.

The potential of the transpired solar collector lays in its simple construction and thus reliable and almost maintenance-free operation. The perforated absorber, which is made of a dark, corrugated metal sheet (usually steel or aluminum), can be integrated in the architectural conception of buildings. It is mounted in a 15-20 cm distance onto the original façade, creating an air gap. This is closed from the sides, so air can enter it only through the perforations. As Fig. 1 shows, the air passes the absorber as AHU fans withdraw fresh air from the plenum. The transpiration of the absorber ensures the transfer of solar heat to fresh air.

Depending on the nominal transpiration of the TSC over a one $\mathrm{m}^{2}$ area, different operational strategies can be determined. High volume flow systems provide lower temperature rise, but they enable the collector to reach high efficiency due to low heat losses from the absorber. Low volume flow systems reach higher temperature rise but the collector efficiency stays lower.

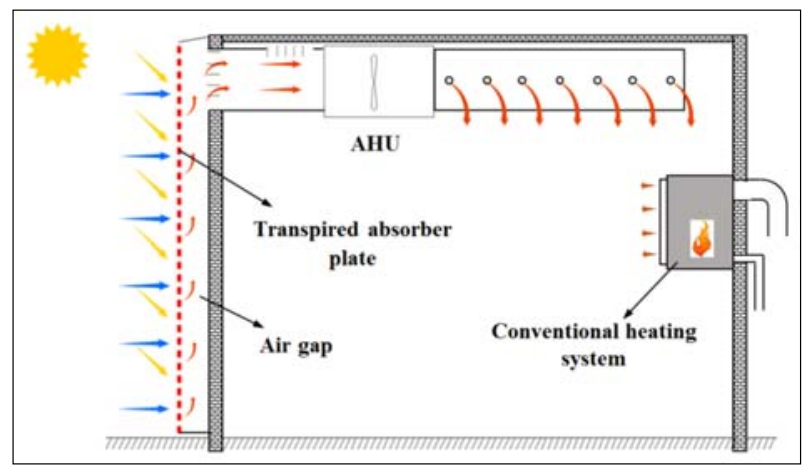

Fig. 1. TSC construction and operational principle

\subsection{Physics of solar air heating with TSC}

Seeing Fig. 1, one could think that in the lack of transparent glazing, the TSC has remarkable thermal losses due to convection to the exterior. According to Kutscher et al. [5], assuming homogeneous suction on the surface of the absorber, one can state that the suction stabilizes the boundary layers on the external side of the absorber, reducing the effect of convective losses solely to the collector edges. This means that for large collector surfaces the convective losses are negligible and wind losses remain small, too. Kutscher et al. [5] describe that to ensure little impact of wind:

- the suction face velocity should be preferably $0.04-0.05 \mathrm{~m} / \mathrm{s}$, but at least $0.02 \mathrm{~m} / \mathrm{s}$,
- at least $25 \mathrm{~Pa}$ pressure drop is to be obtained across the perforated plate, and

- the wall should be designed to have uniform flow through itself.

The flow rate through the surface of the TSC has to be kept between $18-180 \mathrm{~m}^{3} /\left(\mathrm{h} \cdot \mathrm{m}^{2}\right)$ to ensure stable operation. Three air heating strategies can be defined by choosing the appropriate airflow:

- high temperature rise in the range of $18-54$ $\mathrm{m}^{3} /\left(\mathrm{h} \cdot \mathrm{m}^{2}\right)$

- standard operation in the range of 54-108 $\mathrm{m}^{3} /\left(\mathrm{h} \cdot \mathrm{m}^{2}\right)$

- high air volume in the range of 108-180 $\mathrm{m}^{3} /\left(\mathrm{h} \cdot \mathrm{m}^{2}\right)$

High-flow TSC systems perform much better than low flow ones, as the efficiency can reach its highest values when high flow is cooling the absorber, utilizing the most of its heat, reducing all kinds of thermal losses. In Fig. 2 one can see that for a given wind speed the collector efficiency only depends on the air flow rate, which underlines the negligible impact of convective losses depending on ambient temperature.

\subsection{TSC benefits}

The benefit of a transpired solar collector comes together from three sources: solar air heating itself, wall heat recapture and building air destratification.

On the area of the façade where the TSC is installed, an amount of the transmission wall heat can be recaptured (up to $50 \%$ [6]), as the streaming air in the air gap takes it.

In large halls with internal heat production vertical temperature differences in the space can be remarkable. Warm air accumulates under the ceiling, its heat stays unused and the heat losses of the building rise. A TSC system's air ducts mix the solar heated (but still colder) air with this warm upper layer, reducing the temperature vertical difference, destratifying the building air. This brings the heat of the upper layer into the active zone again.

Further benefits can be reached by the combination of the TSC with heat producers and air conditioning systems.

\section{Combustion air preheating}

There are several available options to improve the efficiency of large scale boilers, one of which is the preheating of combustion air. If this is supplied from the ambiance where temperatures can be low, the combustion process itself warms up the air reducing the boiler's efficiency. As previously shown for ventilation air, ambient air can be similarly heated up by a TSC 


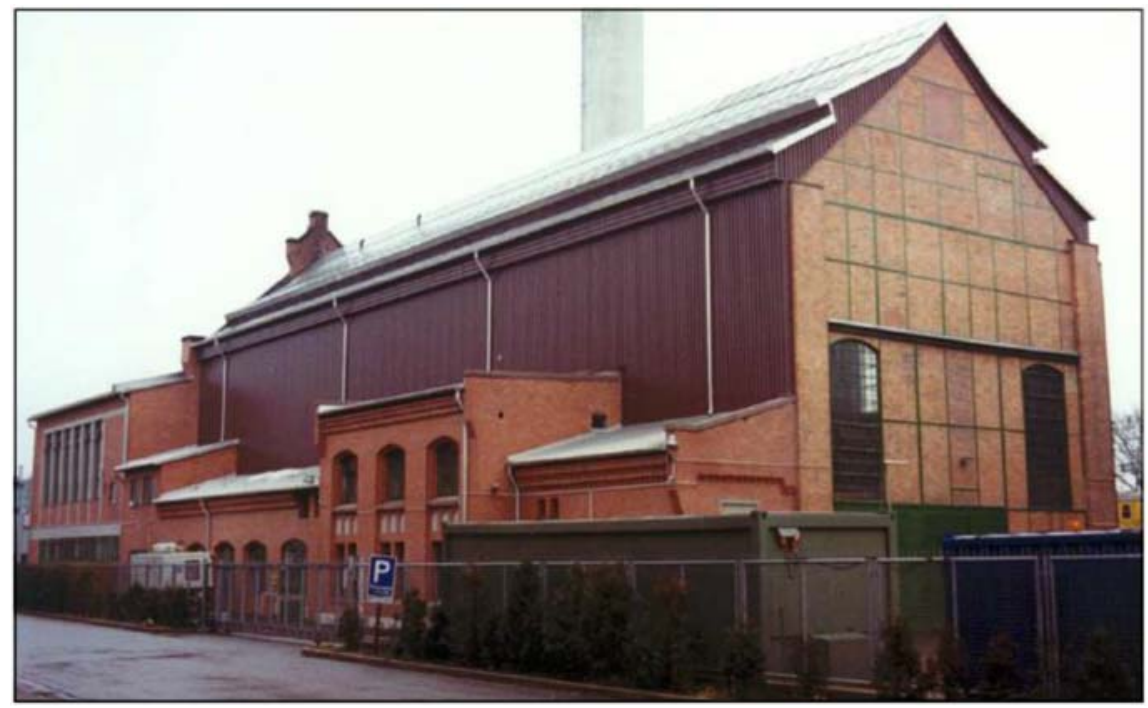

Fig. 2. TSC system of the Göttingen Co-Generation Plant [8]

system, now with the purpose of combustion air preheating. This helps to improve boiler efficiency, reducing fuel consumption and $\mathrm{CO}_{2}$ emission. A low-cost solar air heating system such as the TSC can quickly pay off its first costs if the effect on boiler efficiency is significant. There is little information about the applicability of the TSC for combustion air preheating, as there is only one monitored project available in literature, described below.

\subsection{Göttingen Utility Co-Generation Plant, Germany [7]}

The more than a hundred-year-old boiler house of Göttingen Utility Co-Generation Plant underwent refurbishment in 1993. In order to combine the aesthetical renovation of the façade with energy improvement of the heat production, a TSC system was retrofitted. The new façade had to comply with the architectural features of the old building, so as seen in Fig. 2, a dark brown colour was chosen for the transpired absorber.

The south-east oriented absorber has a total area of $343 \mathrm{~m}^{2}$, providing $40,800 \mathrm{~m}^{3} / \mathrm{h}$ combustion air for three boilers of a total nominal power of $40 \mathrm{MW}$ in the heating season and $7,500 \mathrm{~m}^{3} / \mathrm{h}$ in summer when only DHW heat demand is supplied. These two operation modes make it necessary to control the transpiration of the absorber surface in a way so that the required minimum approach velocity is provided. This means that in winter the entire collector surface takes part in the heat production whereas for summer the lower airflow is heated up by a part of the absorber. The solar-heated air is led from the collector to the burners by an air duct network. The pressure drop of the TSC system including the air ducts is low, so no additional fans had to be installed, the flow is kept in motion by burner fans. As the boilers have a remarkable heat loss over their surfaces, high temperature $\left(\right.$ ca. $40{ }^{\circ} \mathrm{C}$ ) can be measured under the ceiling, where the lost boiler heat accumulates. This heat can be also recovered. The air ducts are led uninsulated under the ceiling so that the solar heated outdoor air (which is usually colder than $40^{\circ} \mathrm{C}$ ) can gain heat from the warm indoor air. Based on the actual intensity of solar radiation combustion air can be taken from the ambiance through the TSC or from below the ceiling. The switching is realized by flaps in the air duct. Every $20 \mathrm{~K}$ temperature rise in the combustion air is reported to have increased boiler efficiency by $1 \%$.

\subsection{Potential for Hungary}

As the twenty-four-year-old Göttingen project is the only documented combustion air preheating system available in TSC literature, there is a need for further research on this topic. In Hungary 210 district heating plants provide heat for 650,000 flats, so any performance improvement in the district heating sector has a positive impact on the national energy household, too. Newer, more sophisticated heat producers require a

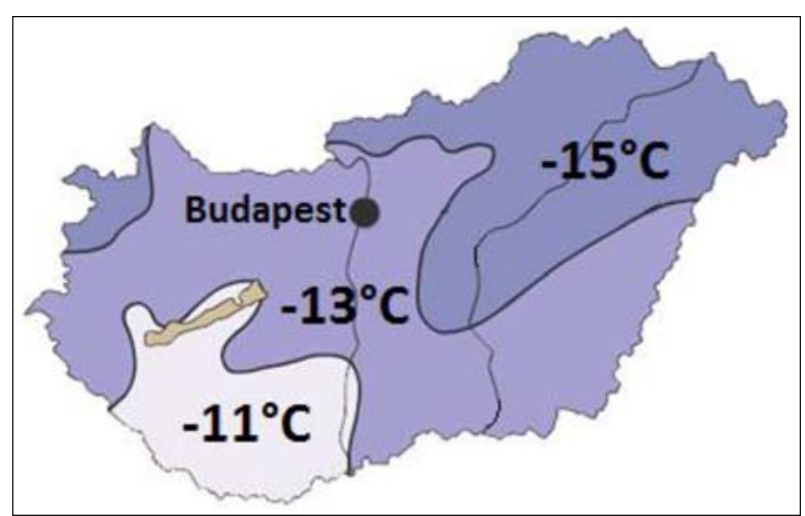

Fig. 3. Design outdoor temperatures in Hungary 
tailor-made approach in terms of performance optimization, however, there are still many old heating plants in Hungary in which a low-budget solution could easily improve system efficiency. In a joint cooperation with the Engineering Faculty of Trakya University the Department of Building Service and Process Engineering of Budapest University of Technology and Economics is researching the potential of solar combustion air preheating focusing on the heating plants of Hungarian district heating providers.

As shown in Fig. 3, the map of Hungary is divided into three regions for which different design outdoor temperatures are to be considered during building heat load calculations. In order to make statements generally valid for the whole country, research must provide results for all the three regions by evaluating one heating plant for each region.

The applicability of the TSC for a district heating plant depends on several factors. Some boilers are provided with combustion air directly from the exterior while others use the indoor air of the boiler house. The improvement of boiler efficiency may be stronger for those taking air from the exterior, because the solar heating can provide a higher temperature rise compared to the base case. Heating plants have to be mechanically ventilated to reach an air exchange rate $n=5 / h$ for safety reasons. The high air exchange rate makes it necessary to heat the supply air and thus the plant itself, so that proper working temperature can be ensured and frost can be avoided at all times. This requires an amount of heat which the plant has to produce but it is not utilized at the supplied consumers. A TSC system in this case can minimize the ventilation heating demand of a plant, too.

For explosion protection reasons the external walls of many heating plants are made of glass panels. These cannot be covered with a TSC surface, as the glass is meant to break first in case of an explosion. Solar air heating for such plants can be realized by roof-mounted TSC ducts, shown in Fig. 4. For the dimensioning results of Horváth et al. [10] can be useful, as they investigated the potential of solar energy on different roof types, including flat roofs.

\section{TSC vs. heat recovery systems}

Transpired solar collectors are heat producers used in air conditioning and ventilation processes. They incorporate both the advantages and disadvantages solar energy utilization systems represent in building heating technologies, however, in their case these must be considered from the air conditioning point of view.

Kozubal et al. [11] simulated the heat delivered by TSC systems for nine US cities in different climate zones. It has been suggested that TSC and heat recovery systems should be compared considering economical and energy aspects in order to determine the best strategy for the ventilation of a building. Reference [12] gives an overview about the pros and cons for solar air heating versus heat recovery and their parallel operation, but in order to describe the effect of performance influencing factors on both sides, detailed system analysis is required. The basic differences can be summarized as follows:

A transpired solar collector's main advantages are the low first costs and the maintenance-free operation as it has no moving parts. The simple construction results in a very reliable operation and a life-expectancy of more than 30 years. A well-designed TSC can displace the heating load in spring and in autumn, but as a solar energy utilization system, without heat storage it is a daytime energy source only. This makes an auxiliary heating system necessary.

Heat recovery units can be of different construction: cross-flow heat exchangers, rotary heat exchangers, coil loop heat recovery, heat pipes are used in air handling units and heat pumps [13-17]. Depending on the construction used, the first costs can be high.

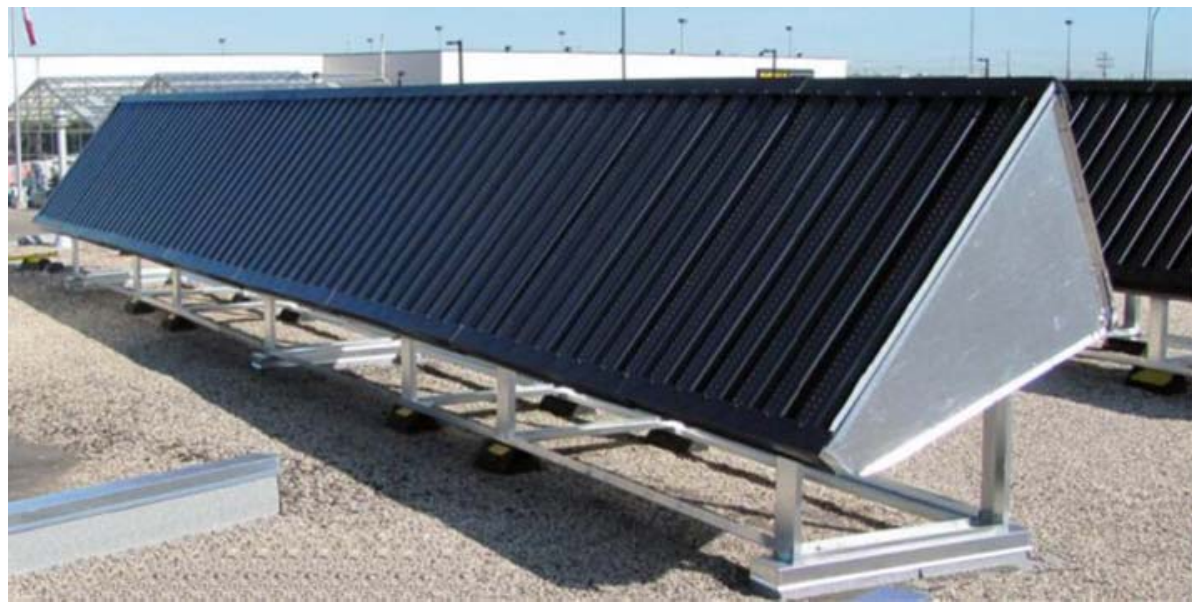

Fig. 4. Modular TSC duct system on a flat roof [9] 
Table 1. Influencing factors of TSC and HRV efficiency

\begin{tabular}{llc}
\hline & Transpired solar collector & Heat recovery unit \\
\hline Façade surface area & large, possibly southern & indifferent \\
Glazing ratio of façade & low & high \\
Height of heated space & high & indifferent \\
Yearly sum of solar radiation & high & indifferent \\
Internal heat production & low & high \\
Temperature difference between outdoor and supply air & low & high \\
\hline
\end{tabular}

Due to moving parts and dirt accumulation they require regular maintenance. Heat recovery operates 24 hours a day, preheating in winter and precooling in summer. In order to realize the heat exchange, air ducts have to cross or the necessary pipeline has to be built. Their operation requires internal heat production in the space so that the extract air contains enough heat for warming up the supply air (winter case).

In order to be able to make the right choice between TSC or heat recovery, it is necessary to be aware of the factors which influence the performance of the two systems. As their benefits originate from different sources, it is expected that the right choice can always be found based on architectural aspects, building use and climate. Table 1 gives an overview about the conditions for efficient operation for both systems.

Buildings with large empty surfaces on the façade and low glazing ratio offer advantageous circumstances for solar air heating. First, the even transpiration of the perforated absorber is not hindered by obstacles (windows). Second, the higher glazing ratio results in higher solar gains, which minimize the need for solar air heating. This makes solar air heating very suitable for large halls, such as industrial and commercial buildings. Large TSC areas make it possible to regain a remarkable amount of the transmission heat loss of a wall surface, where the TSC is installed. If the heated space is high (like in most industrial buildings), the destratification effect is higher, which can be effectively reduced by the TSC. This way a higher internal height of the heated space enhances the benefits of a TSC system. Transpired solar collectors have a high share in the heating energy production in locations with a long, cold heating season, but high solar radiation at the same time.

Looking at Table 1 it could seem that the efficient operation of transpired solar collectors require more specific environment than heat recovery. It has to be noted that most of the requirements for TSC serve the maximization of additional benefits, such as wall heat recapture and building air destratification. During the comparison of TSC and heat recovery use in an air conditioning system all benefit sources of the TSC have to be taken into consideration. Only this way is it possible to get reliable results about the benefits of the two systems. The evaluation of a reference building with TSC and heat recovery is an objective of further research.

\section{Roof ventilation}

The installation of transpired solar collectors on a building roof ensures new benefits of the system. Other than one would first think, the absorbent surface which reaches high temperatures during hot and sunny summer days does not increase the cooling load of the building. The natural airflow described above comes to be too, if the collector is not installed for solar air heating purposes, but simply as a ventilated, double roof structure. The absorber plate, which reaches high temperatures, evokes the natural airflow. The air in the cavity rises driven by the buoyant force, leaves through upper perforations and at the same time colder ambient air streams into the air gap beneath.

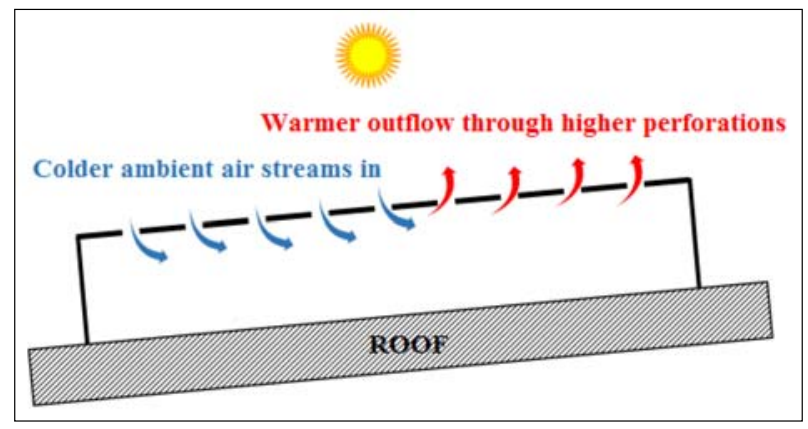

Fig. 5. Natural ventilation in a roof-mounted TSC

The described process is visualized in Fig. 5. The continuous ventilation thermally decouples the absorber plate from the back plate which stands for the actual building roof. The TSC reduces thermal load from the building roof this way.

\section{Nocturnal radiant air cooling}

The night time ventilation of building structures has been proven to reduce the cooling load of buildings in climates with moderate temperature peaks and high enough daily temperature range. However, high cool- 


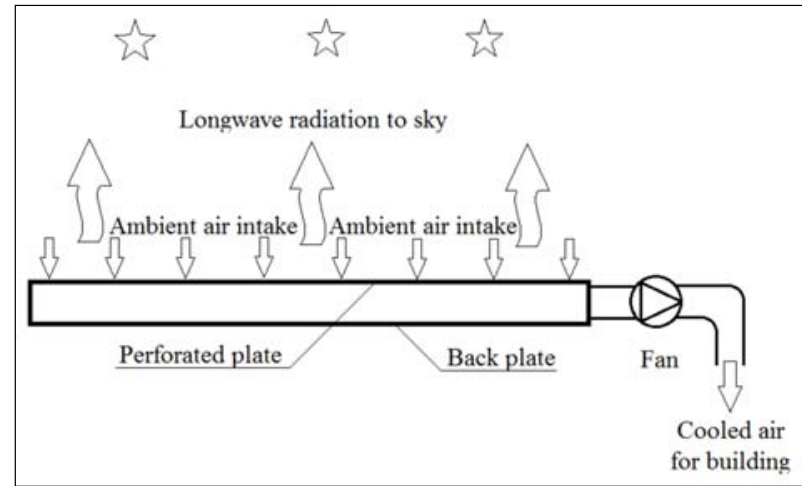

Fig. 6. Nocturnal air cooling with TSC

ing loads come to be in locations in warm climatic zones where the daily minimum temperatures do not provide enough cold to reach significant cooling performance. Transpired solar collectors installed on building roofs can act as radiators to the cold night sky, as Fig. 6 shows.

The absorber which has high emissivity emits heat to the cold night sky in the form of long-wave radiation. This results in the cooling down of the plate. Similarly as in solar air heating, the transpiration of the plate is bound to heat transfer, and this way the cold plate has the ability to cool down the air stream. This mode of operation opens up new uses to the transpired solar collector as a system of passive cooling.

\section{Conclusions}

Transpired solar collectors are getting better recognized as an alternative heating opportunity around the world. Their main advantage is the reliable operation due to their simple construction. They can also operate in an efficient way when combined with other system elements, such as conventional heat producers. Literature reports about several cases when TSC was integrated into a multi-element energy producing system, however, very few results have come to light about their operation as a combustion air preheater and about TSC and heat recovery comparison.

Extensive research is planned to find out the applicability of transpired solar collectors for the combustion air preheating of district heating boiler houses in Hungary.

Whether to choose a transpired solar collector or a heat recovery system for a certain building type, system usage and geographical location has to be investigated considering several influencing factors of system efficiency. Research tasks, problems and efficiency-influencing factors are presented in this paper.

Besides solar air heating, transpired solar collectors can be advantageous building elements for reducing cooling loads in summer. Roof ventilation significantly reduces the temperatures between the ex- posed absorber plate and the actual building roof, thus minimizing the heat gain reaching the interior. Nocturnal radiant cooling helps to reduce air temperatures which increases the effect of night-time ventilation of the building mass, helping to reduce air conditioning peaks of the next day.

\section{Acknowledgements}

Supported by the ÚNKP-17-3-III New National Excellence Program of the Ministry of Human Capacities. Author B. Bokor hereby expresses thanks for the support.

OQ Kiválóság

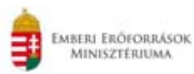

\section{References}

[1] Hollick J. C. (1994). Unglazed Solar Wall Air Heaters. Renewable Energy, 5. Part I. 415-421.

[2] Eryener D., Akhan H. (2012), Theoretical and Experimental Investigation of Perforated Solar Air Collector Coupled to a Capillary Radiant Heating System. In: Proceedings of 9th International Conference on Heat Transfer, Fluid Mechanics and Thermodynamics. Malta

[3] Eryener D., Akhan H. (2018), Building integrated solar air heating with waste heat utilisation. Energy Conversion and Management, 157, 136-145.

[4] Ameri M., Gholampour M., Sheykh Samani M. (2014), Experimental study of performance of Photovoltaic-Thermal Unglazed Transpired Solar Collectors (PV/UTCs): Energy, exergy, and electrical-to-thermal rational approaches. Solar Energy 110, 636-647.

[5] Kutscher C. F., Christensen C. B., Barker G. M. (1993), Unglazed transpired solar collectors: Heat loss theory. J. Sol. Energy Eng., 115(3), 182-188.

[6] RETScreen International Engineering \& Cases Handbook: Solar Air Heating Project Analysis Chapter. National Resources Canada 2001-2004.

[7] Low Cost, High Performance Solar Air-Heating Systems Using Perforated Absorbers. Göttingen Utility Co-Generation Plant, Germany. IEA Solar Heating and Cooling Report No. SHC.T14.Air.I, pp. 40-55. September, 1999

[8] http://solarwall.com/modules/download_gallery/dlc. php?file $=190$

[9] http://solarwall.com/en/products/solarwall-air-heating/ solarduct.php\#prettyPhoto[gallery]/4/

[10] Horváth M., Kassai-Szoó D., Csoknyai T. (2016), Solar energy potential of roofs on urban level based on building typology. Energy and Buildings, 111, 278-289.

[11] Kozubal E., Deru M., Slayzak S., Norton P., Barker G., McClendon J. (2008), Evaluating the performance and economics of transpired solar collectors for commercial applications. In: Proceedings of ACEEE Summer Study on Energy Efficiency in Buildings, Pacific Groove, CA

[12] http://solarwall.com/media/images-articles/SolarWallwith_Heat_Recovery_Systems.pdf 
[13] Nyers J., Pek Z. (2014), Mathematical model of heat pumps' coaxial evaporator with distributed parameters. Acta Polytechnica Hungarica, 11(10), 41-54.

[14] Nyers J. (2016), COP and economic analysis of the heat recovery from waste water using heat pumps, International J. Acta Polytechnica Hungarica, 13(5), 135-154.

[15] Takács J. (2015), Enhance of the efficiency of exploitation of geothermal energy. International symposium, Subotica, Serbia, Proceedings EXPRES 2015, pp. 46-49.
[16] Petráš D., Lulkovičová O., Takács J., Füri B. (2005), Obnovitel'nézdroje energie na vykurovanie. In: Vykurovanie rodinných a bytových domov. Bratislava: Jaga, pp. 193217, ISBN 80-8076-012-8.

[17] Petráš D., Lulkovičová O., Takács J., Füri B. (2009), Obnovitel'né zdroje energie pre nízkoteplotné systémy. Bratislava: Jaga Group, s.r.o., 221 s. ISBN 978-80-8076-075-5 